$\mathbb{1}$

Nordiska ministerrådet

NOTAT 03/2018

\title{
Omverdenens syn på de nordiske landene
}

Dette notatet handler om hvordan befolkningene i andre land oppfatter de nordiske landene. Undersøkelsen fokuserer på landenes styresett og samfunnsmodell.

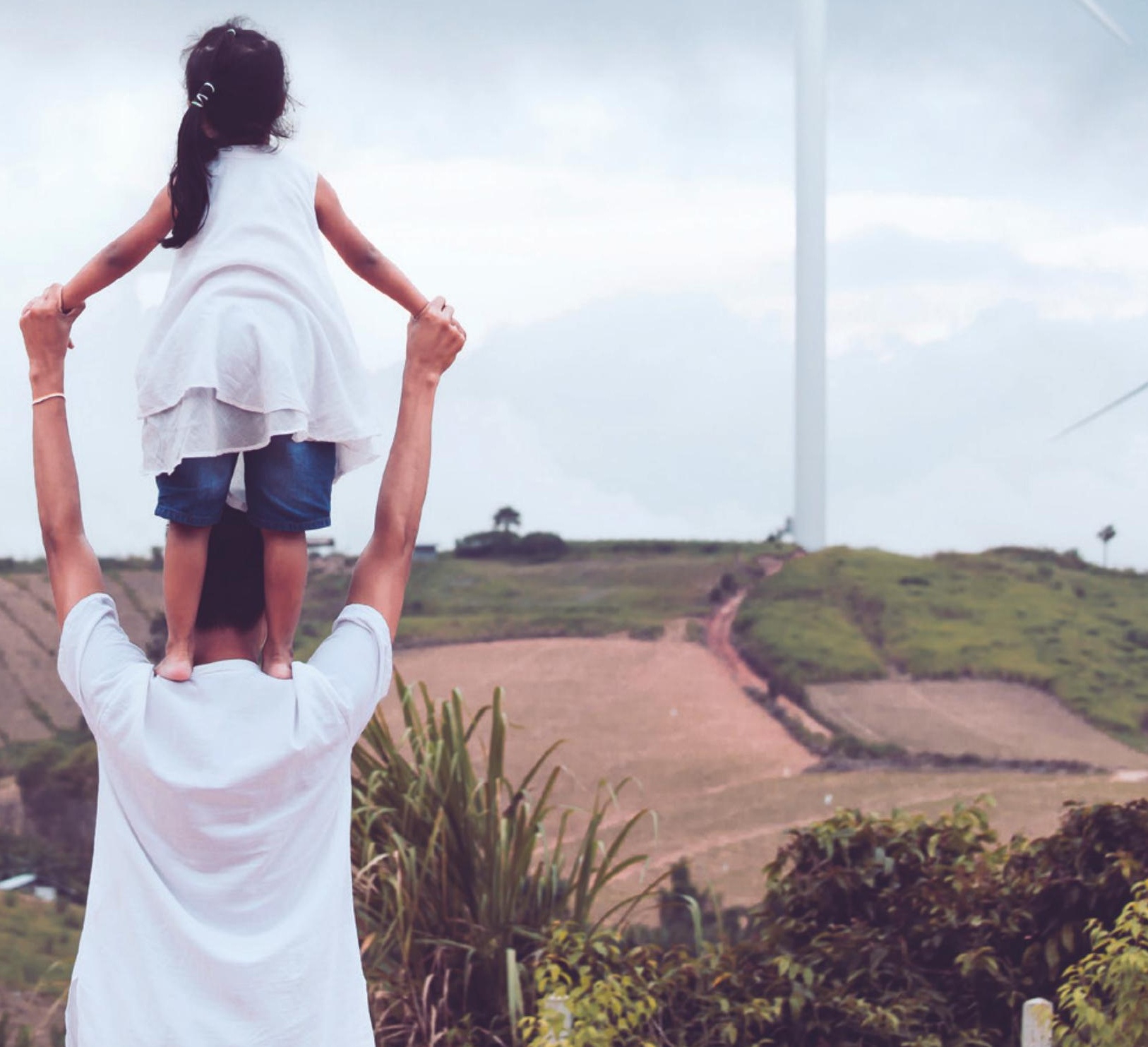


Omverdenens syn på de nordiske landene

Truls Stende

ANP 2018:797

ISBN 978-92-893-5727-2 (PRINT)

ISBN 978-92-893-5728-9 (PDF)

ISBN 978-92-893-5729-6 (EPUB)

http://dx.doi.org/10.6027/ANP2018-797

(C) Nordisk ministerråd 2018

Layout: Mette Agger Tang

Forsidefoto: Unsplash.com

\section{Det nordiske samarbeidet}

Det nordiske samarbeidet er en av verdens mest omfattende regionale samarbeidsformer. Samarbeidet omfatter Danmark, Finland, Island, Norge og Sverige samt Færøyene, Grønland og Åland.

Det nordiske samarbeidet er både politisk, økonomisk og kulturelt forankret, og er en viktig med-spiller i det europeiske og internasjonale samarbeidet. Det nordiske fellesskapet arbeider for et sterkt Norden i et sterkt Europa.

Det nordiske samarbeidet ønsker å styrke nordiske og regionale interesser og verdier i en global omverden. Felles verdier landene imellom bidrar til å styrke Nordens posisjon som en av verdens mest innovative og konkurransekraftige regioner.

\section{Nordisk ministerråd}

Nordens Hus

Ved Stranden 18

DK-1061 København K

www.norden.org

Last ned nordiske publikasjoner: www.norden.org/nordpub 


\section{Omverdenens syn på de nordiske landene}




\section{Innhold}

07 Sammendrag

08 Innledning

11 De nordiske landenes varemerker

12 Styresett og samfunnsmodell de nordiske landenes fortrinn

17 Konklusjon

18 Vedlegg

19 Kilder 


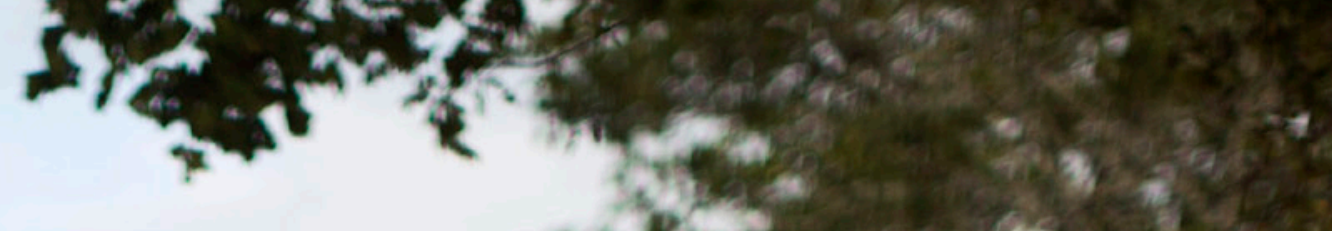
Xtento

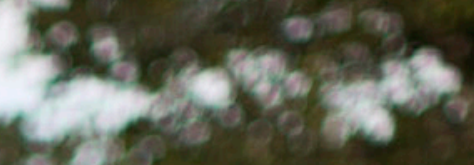
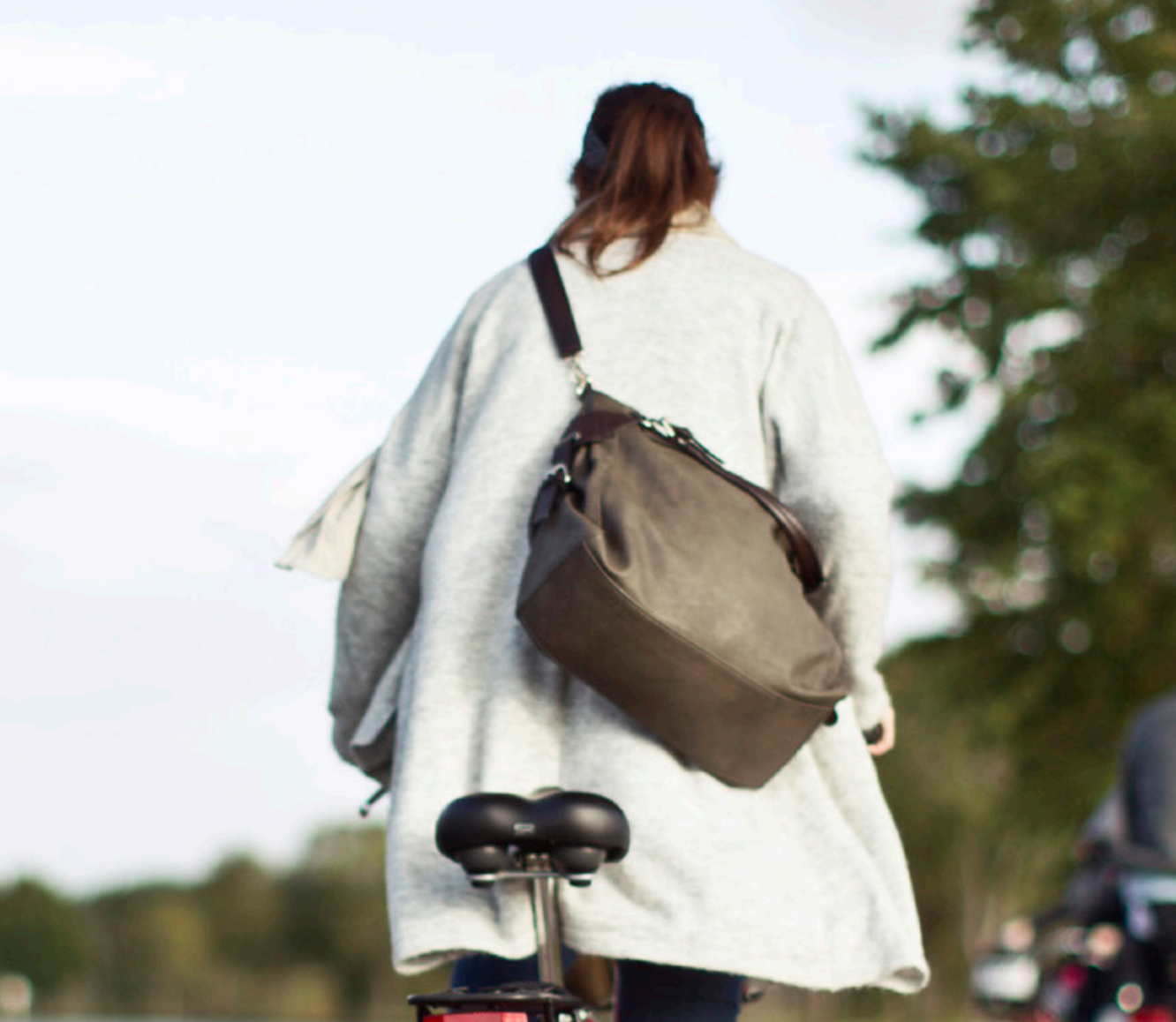


\section{Sammendrag}

Denne rapporten handler om hvordan omverdenen ser på de nordiske landene. Hvordan land oppfattes av omverdenen er viktig - ettersom det påvirker for eksempel handel, investeringer og turisme.

Vår undersøkelse tyder på at de nordiske landene oppfattes positivt i andre land. De skårer nemlig ganske godt i tre undersøkelser som rangerer land etter hvor sterke deres varemerker er.

Undersøkelsen gir ganske sterke indikasjoner på at omverdenen har et godt inntrykk av de nordiske landenes samfunnsmodell og styresett, noe som er sentralt for at Norden skal lykkes med å eksportere sine nordiske løsninger og modeller til omverdenen. De nordiske landene oppnår svært gode resultater når oppfatningen av disse aspektene måles. Det indikerer at omverdenen mener de nordiske landene styres godt, tar vare på miljøet, bekjemper fattigdom, behandler borgerne bra og sørger for fred og sikkerhet.

De nordiske landene ser også ut til å ha ganske motstandsdyktige varemerker, som tåler litt negativ omtale i utenlandske medier. Det tyder undersøkelser av Sveriges og Danmarks omdømme etter flyktningkrisen på. De nordiske landene resultater er også generelt stabile; nordiske land inntar lignende plasseringene år etter år.

De nordiske landene oppfattes ikke like positivt når det gjelder turisme, kulturarv og kultur.

Metoden vi har brukt i denne undersøkelsen, er å innhente analyser av hvordan de enkelte nordiske landene oppfattes av omverdenen. Deretter har vi sett analysene i sammenheng, på leting etter et mønster som kan si oss noe om hvordan hele Norden oppfattes. Undersøkelsen kan antyde noen mønstre og tendenser, selv om den bærer preg av at datagrunnlaget er mangelfullt. 


\section{Innledning}

I løpet av de siste årene har en idé spredt seg om at land også kan ses på som kommersielle foretak, som konkurrerer på et internasjonalt marked. På dette markedet er det en fordel å ha et godt varemerke, eller «brand». Folks oppfatning av et lands varemerke påvirker nemlig om de ønsker å reise dit, investere der eller handle dets varer, på samme måte som konsumenters oppfatning av Coca-Cola påvirker om de vil kjøpe den flasken med brus. ${ }^{1}$

For de nordiske landene er omdømme viktig. De ønsker å dele sine løsninger med resten av verden, noe de nordiske statsministrenes initiativ Nordic Solutions to Global Challenges er et eksempel på. Blant annet vil de nordiske landene vise frem effektene av likestilling og nordiske velferdsløsninger. ${ }^{2}$ En forutsetning for at de nordiske landene skal lykkes med dette, er at de oppfattes som vellykkede land med godt fungerende samfunnssystemer. I denne undersøkelsen har vi derfor fokusert på hvordan de nordiske landenes styresett og samfunn oppfattes.

Videre gir det makt og innflytelse at man oppfattes som et vellykket og godt land. Det er nyttig for de små nordiske landene, som har begrenset med maktmidler sammenlignet med større land. Hvis de nordiske landene har et godt omdømme, kan de oppnå myk makt, det vil si egenskapen til å få andre til å ønske det samme som en selv. Med myk makt kan man oppnå sine mål fordi andre land har et positivt syn på landets verdier, og ønsker å etterligne det. ${ }^{3}$

At omdømme er viktig for de nordiske landene, og at de ser en klar nytte av det, kan man også se ved at de har utarbeidet en strategi for internasjonal profilering og posisjonering av Norden. Det langsiktige målet med strategien er at Nordens internasjonale konkurranseevne og innflytelse skal styrkes. ${ }^{4}$

Det finnes flere aktører som måler hvordan land oppfattes av omverdenen, og hvor sterke de forskjellige landenes varemerker er. De publiserer lister hvor landene er rangert mot hverandre, fra landet med det beste varemerket til landet med det dårligste. I det neste kapitlet ser vi på hvor de nordiske landene plasserer seg på tre slike rankinger.

Denne undersøkelsen kan ses i sammenheng med to tidligere rapporter fra analyse- og statistikkenheten i Nordisk ministerråd. Analyse 2/2017 Er Norden best $i$ verden handlet om hvordan Norden gjorde det på internasjonale indekser som måler innbyggernes lykke, velstand, korrupsjonsnivåer, osv.

Dinnie, Keith (2017). Nation Branding - Concepts, Issues, Practice

Norden.org: Nordic Solutions to Global Challenges

Nye, Joseph S (2004). Soft Power - The Means to Success in World Politics

Nordisk ministerråd (2015). Strategi for internasjonal profilering og posisjonering av Norden 2015-2018 
Disse indeksene er bygget opp med mange objektive indikatorer. Denne undersøkelsen har et mer subjektivt utgangspunkt; den handler om hvordan resten av verden oppfatter de nordiske landene. Analyse 3/2017 Ett värdefullt samarbete presenterte resultatene av en spørreundersøkelse om den nordiske befolkningens holdninger til det nordiske samarbeidet. Nå skifter vi perspektiv, og undersøker hva folk utenfor Norden synes om de nordiske landene.

Metoden vi har brukt i denne undersøkelsen, er å innhente analyser av hvordan de enkelte nordiske landene oppfattes av omverdenen. Deretter har vi sett disse i sammenheng, på leting etter et mønster som kan si oss noe om hvordan hele Norden oppfattes. Undersøkelsen kan antyde noen mønstre og tendenser, samtidig som den bærer preg av at datagrunnlaget er mangelfullt. Ikke alle de nordiske landene har gjennomført like omfattende kartlegginger av hvordan de oppfattes, og de kartleggingene vi har fätt tilgang til, har blitt gjennomført på forskjellige tidspunkter. Danmark har for eksempel ikke gjennomført noen større generell kartlegging i de siste årene, som vi kjenner til, og heller ikke Island. Det er også sparsomt med informasjon om enkeltlands detaljerte resultater i de offentlig tilgjengelige undersøkelsene. Til slutt er det også viktig å merke seg at dette er en undersøkelse av hvordan de nordiske landene, og ikke "Norden», oppfattes. 


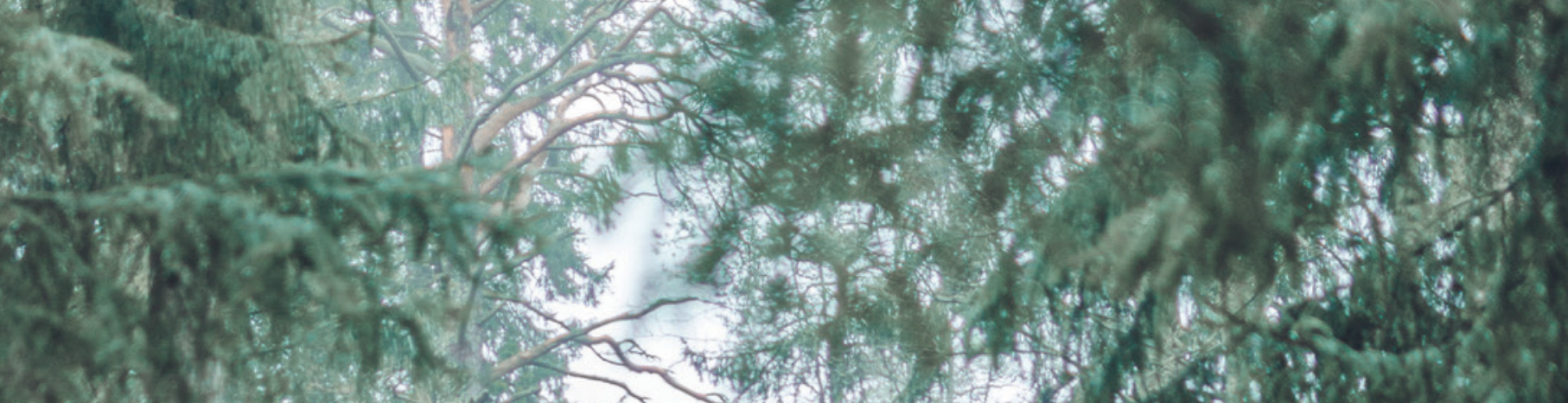

34
34

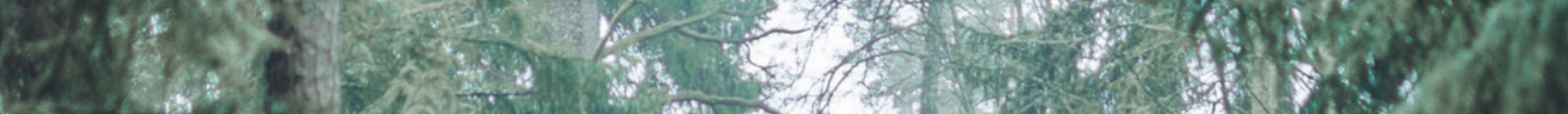

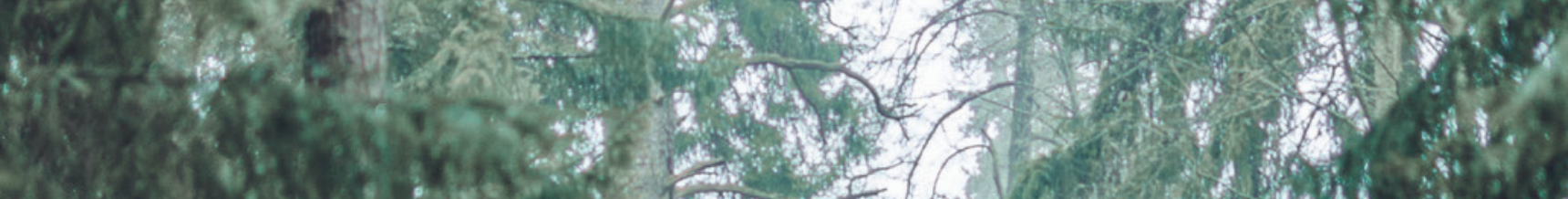

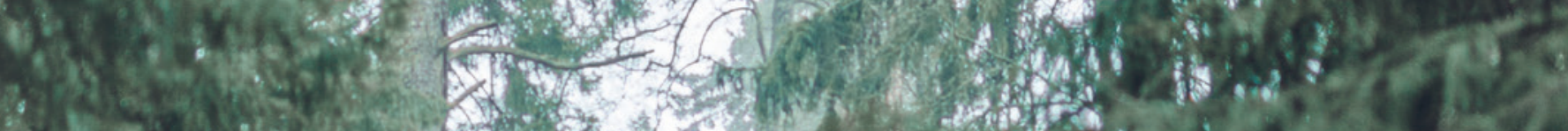

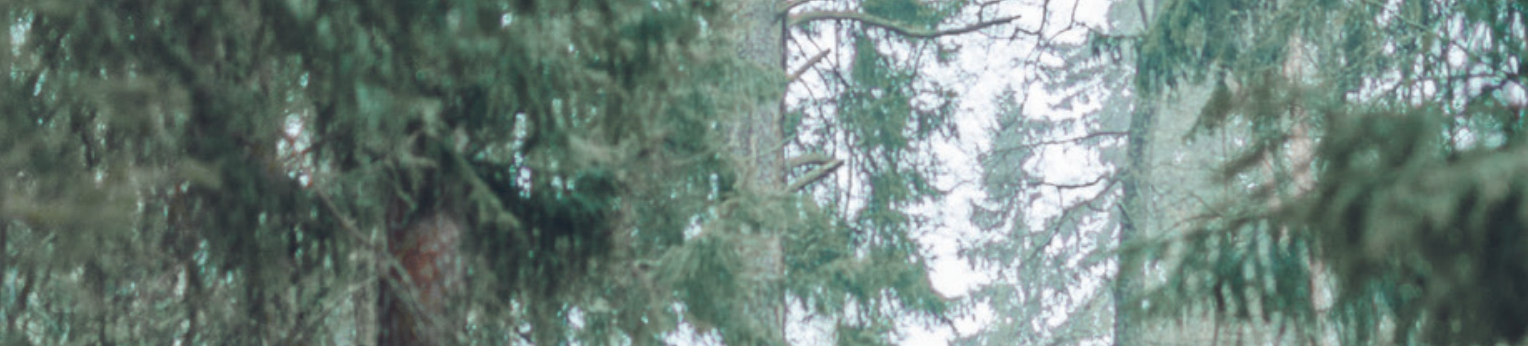

(2)

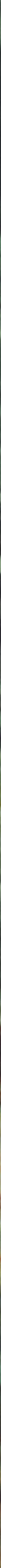




\section{De nordiske landenes varemerker}

Vi har sett på hvor de nordiske landene plasserer seg i tre undersøkelser av lands varemerker. I undersøkelsene er landene rangert etter hvor sterke deres varemerker er, basert på hvordan de oppfattes av et utvalg respondenter i 8-20 land. Respondentene er ikke ment å skulle reflektere hele befolkningen i landene, men en del, for eksempel de som er på internett. De nordiske landenes plasseringer er oppsummert i tabell 1 .

Som vi ser, plasserer de nordiske landene seg ganske godt på disse tre undersøkelsene. De inntar som beste en tredje plass og som dårligst en 17. plass. I to av undersøkelsene inngår ikke Island.

På Futurebrand 2014-2015 ligger alle de nordiske landene innenfor topp 15. Sverige ligger høyest, på 4. plass, mens Island er nederst på 15. plass. Japan, Sveits og Tyskland topper listen. I The Anholt-Gfk Roper Nation Brands Index Report 2016 kommer Danmark på 13. plass, Finland på 17. plass og Sverige på 10. plass. Island og Norge var ikke med i undersøkelsen i 2016. Norge var med i undersøkelsen i 2014, og da kom Norge på 13. plass. På Country RepTrak - The World's Most Reputable Countries ligger de fire nordiske landene som omfattes av undersøkelsen blant de åtte beste. Se vedlegget for mer informasjon om hver enkelt undersøkelse.

Vi skal nå gå litt mer i dybden i de nordiske landenes resultater, og vi fokuserer på kategoriene som måler styresett og samfunnsmodell. Vi ser også litt nærmere på kultur og turisme.

\begin{tabular}{|c|c|c|c|c|c|c|c|}
\hline & DA & $\mathbf{F I}$ & NO & IS & SE & $\begin{array}{l}\text { Norden } \\
\text { gjenn- } \\
\text { omsnitt }\end{array}$ & $\begin{array}{c}\text { Totalt } \\
\text { antall } \\
\text { land }\end{array}$ \\
\hline $\begin{array}{l}\text { Futurebrand } \\
2014-2015\end{array}$ & 9 & 13 & 6 & 15 & 4 & 9 & 118 \\
\hline $\begin{array}{l}\text { The Anholt-Gfk } \\
\text { Roper Nation } \\
\text { Brands Index } \\
2016\end{array}$ & 13 & 17 & $\begin{array}{l}\text { Ikke } \\
\text { med }\end{array}$ & $\begin{array}{l}\text { Ikke } \\
\text { med }\end{array}$ & 10 & 13 & 30 \\
\hline $\begin{array}{l}2017 \text { Country } \\
\text { RepTrak - The } \\
\text { World's Most } \\
\text { Reputable } \\
\text { Countries }\end{array}$ & 8 & 7 & 6 & $\begin{array}{l}\text { Ikke } \\
\text { med }\end{array}$ & 3 & 6 & 55 \\
\hline
\end{tabular}

Tabell 1

De nordiske landenes plasseringer i tre undersøkelser 


\section{Styresett og samfunnsmodell - de nordiske landenes fortrinn}

Et godt utgangspunkt for å undersøke hvordan omverdenen ser på de nordiske landenes styresett og samfunn, er The Anholt-GfK Roper Nation Brands Index. Vi har innhentet offentlige tilgjengelige rapporter for Finland, Norge og Sverige. ${ }^{5}$ Finlands rapport er fra 2016, Sveriges fra 2017 og Norges fra 2014. Island og Danmark har ikke kjøpt undersøkelsen i løpet av de siste årene, så vi kjenne ikke til disse to landenes resultater.

Landenes resultater er bygget opp rundt respondentenes oppfatning av seks dimensjoner ved landet:

1. Landet som turistdestinasjon

2. Om det er land man ønsker å flytte til eller investere i

3. Landets varer og tjenester

4. Hvordan landet styres

5. Landets kultur

6. Landets befolkning ${ }^{6}$

Figur 1, 2 og 3 viser resultatene til Finland i 2016, Norge i 2014 og Sverige i 2017. Figurene viser hvilken plassering landet fikk i forhold til de andre landene som var med i det årets undersøkelse, i de forskjellige kategoriene. Av figur 1 kan vi for eksempel se at Finland var nummer åtte når det gjaldt styresett, men blant de svakere landene i undersøkelsen når det kom til om landet hadde interessante historiske bygninger og kulturarv.

Figurene viser at de nordiske landene skårer ganske likt i undersøkelsen. De gjør det alle godt i styresett-kategorien. Den måler om omverdenen mener landet har kompetente og ærlige regjeringer, om borgerne behandles med respekt og rettferdighet, om det er fred og sikkerhet i landene, om landene beskytter miljøet og om de bidrar til å redusere fattigdom. ${ }^{7}$ Sverige kommer på en tredje plass i kategorien i 2017, Norge kommer på åttende plass i 2014, mens Finland kommer på åttende plass i 2016.

De fullstendige resultatlistene i de forskjellige kategoriene i undersøkelsen ikke er offentlig tilgjengelige. Vi kan derfor ikke si noe bombastisk om hvor gode de nordiske landenes plasseringer er samlet sett. Men en tredjeplass og to åttendeplasser tyder på ganske gode plasseringer innenfor styresett-kategorien.

\footnotetext{
5 For Finland: Finland Promotional Board (2016). Results for Finland, The Anholt-GFK Roper Nation Brands Index 2016 Report, Summary of Finland's nation brand in year 2016; GfK Public Affairs \& Corporate Communications (2014). For Norge: The Anholt-GfK Roper Nation Brands Index 2014 Report Prepared for Norway; For Sverige: Visit Sweden (2017) Den Internationella bilden av Sverige som land - Så står Sverige i världen enligt Nation Brands Index. 

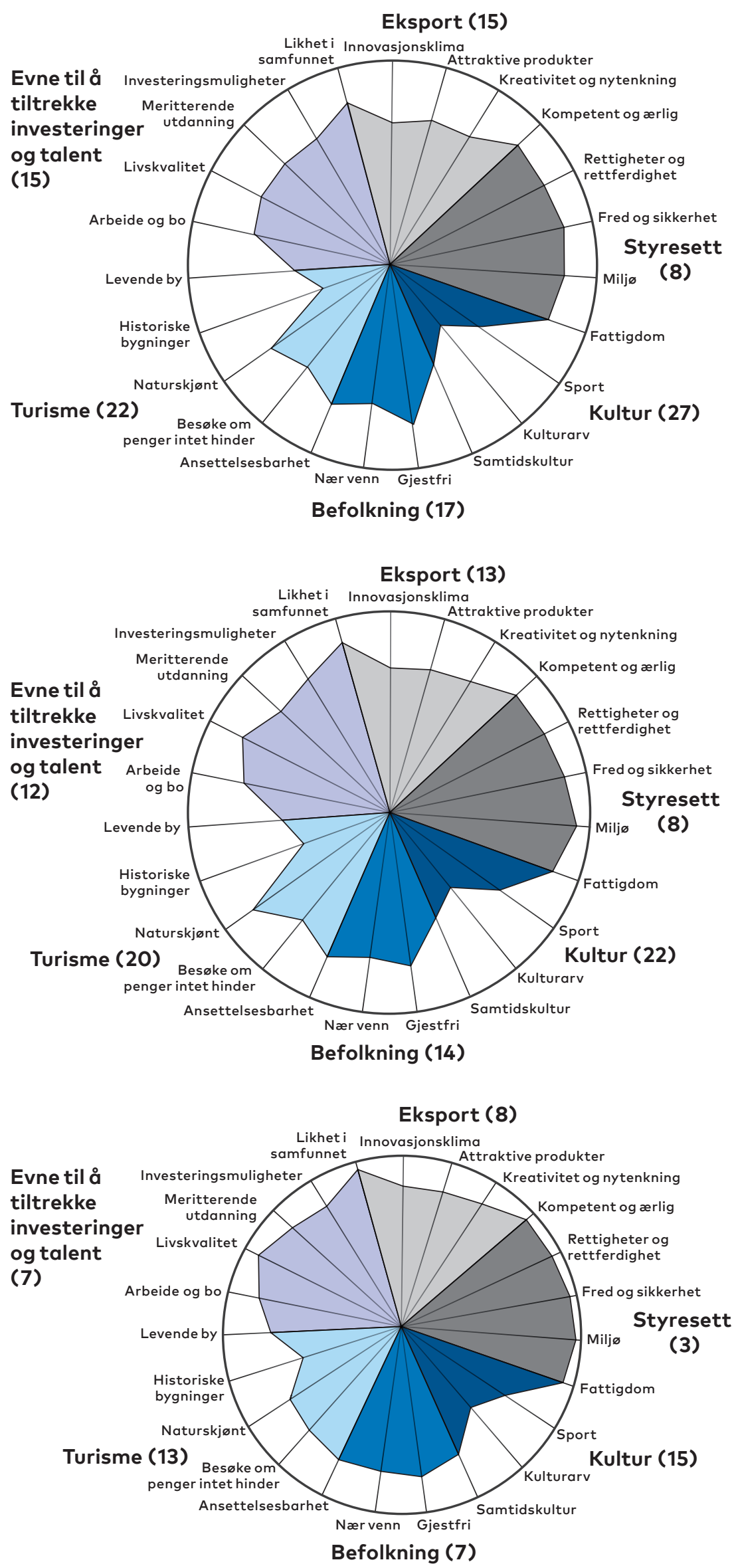

Figur 1

The Anholt-GfK Roper Nation Brands for

Finland 2016

Figur 2

The Anholt-GfK

Roper Nation Brands for Norge 2014

\section{Figur 3}

The Anholt-GfK

Roper Nation Brands for Sverige 2017 
Det er rimelig å anta at Danmark ville inntatt en lignende plassering. Vi kommer tilbake til Island litt senere.

Hvis vi ser litt nærmere på analysene i de tre undersøkelsene, forsterker de inntrykket av at omverdenen ser på de nordiske landene som godt styrte. Ifølge analysene ses Norge på som et land som styres godt, både innenrikspolitisk og utenrikspolitisk. Norges omdømme styrkes av at landet er kjent som et egalitært og miljøvennlig samfunn. ${ }^{8}$ Omverdenen har et positivt bilde av Sveriges arbeid med menneskerettigheter, fattigdomsbekjempelse og miljø. Mange deler også oppfatningen av at Sverige er et godt land å bo og leve i, mye takket være at det svenske samfunnet anses å ha en høy grad av likestilling og høy livskvalitet. ${ }^{9}$ Finland ses på som et land som tar ansvar for internasjonal fred og sikkerhet, og som er kompetent og ærlig styrt. ${ }^{10}$

Island har som nevnt ikke kjøpt en undersøkelse fra The Anholt-GfJ Roper Nation Brands Index i løpet av de siste årene. Vi har imidlertid fått informasjon om hvordan landet gjorde det i Futurebrand 2014-2015, som er en annen undersøkelse av lands varemerker. Samlet sett skårer Island i denne undersøkelsen ganske likt som Sverige, Finland og Norge i The Anholt-GfJ Roper Nation Brands Index, hvis man ser stort på det, se figur 4.

\section{Figur 4}

Futurebrand 2014-2015 for Island

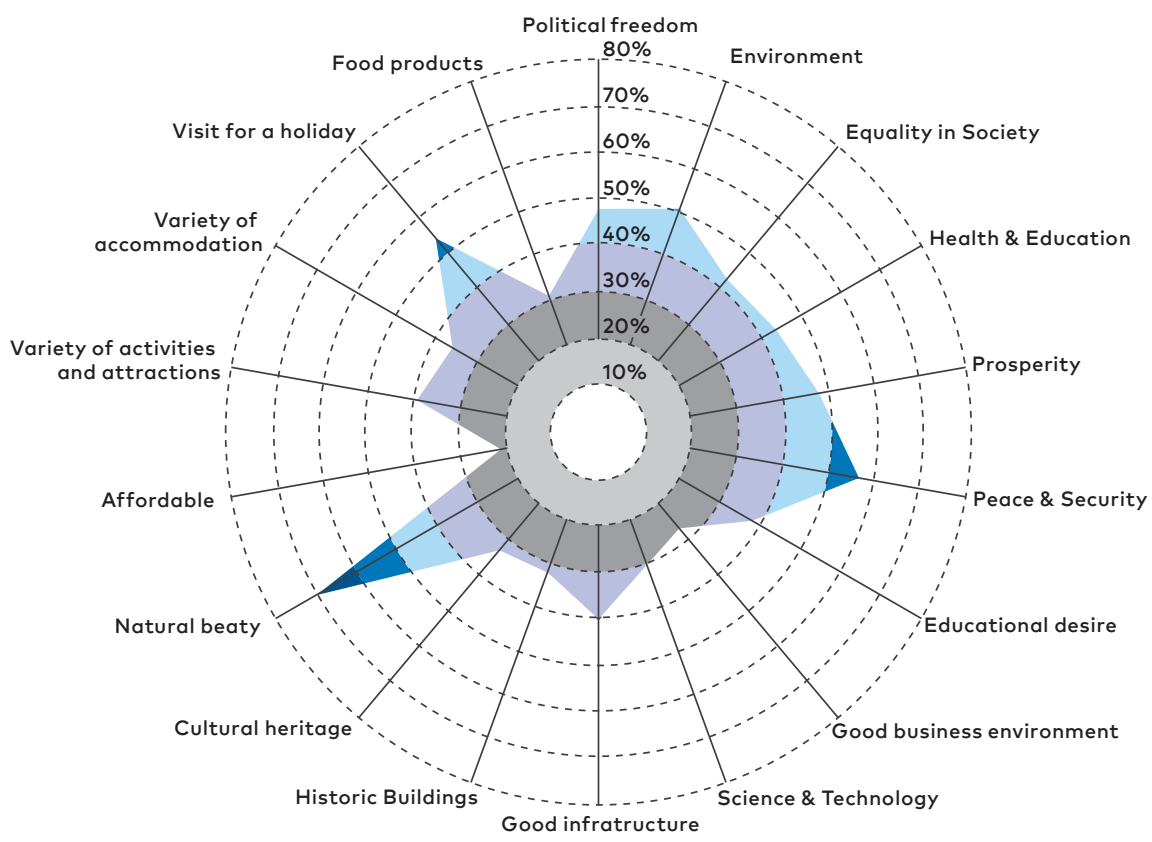

GfK Public Affairs \& Corporate Communications (2014). The Anholt-GfK Roper Nation Brands Index 2014 Report Prepared for Norway

Visit Sweden (2017). Den Internationella bilden av Sverige som land -Så står Sverige $i$ världen enligt Nation Brands Index

10 Finland Promotional Board (2016). Results for Finland, The Anholt-GFK Roper Nation Brands Index, 2016

Report, Summary of Finland's nation brand in year 2016 
Når vi er opptatt av hvordan landenes samfunnssystemer oppfattes, er det er interessant å kikke nærmere på FutureBrands undersøkelse fra 2014-2015. Den rangerer landene i flere kategorier, og to av disse er relevante i denne sammenhengen: "Value system» og "Quality of Life». "Value system» handler om respondentenes mening om den politiske standarden, miljøstandarden og toleransen i landet. I denne kategorien gjør de nordiske landene det veldig bra, de havner på første, fjerde, sjette, syvende og åttende plass. "Quality of Life" handler om helse og utdanning, levestandard, om man ville studert eller bo der, samt sikkerhet og trygghet. Her havner de nordiske landene på andre, tredje, fjerde og tiendene plass (Island havner utenfor topp 10).

I Country RepTrak - The Worlds Most Reputable Countries gjør også de nordiske landene det godt i kategorien "effective government", som er en av tre kategorier undersøkelsen er bygget opp rundt. De nordiske landene som inngår i undersøkelsen inntar første-, tredje-, fjerde- og sjetteplassen. De nordiske landene ligger lengre bak i kategorien for en avansert økonomi (2., 6., 9. og 10. plass) og om det er et godt sted å leve (4., 7. og 8. plass, Danmark ikke på topp 10). Men de gjør det fortsatt veldig godt.

\section{Noen svakheter innen kultur og turisme}

Matrisene fra Norge, Sverige og Finlands undersøkelser (figur 1, 2 og 3) viser at det er noen områder i The Anholt-GfJ Roper Nation Brands Index hvor de nordiske landene ikke gjør det så godt, og det er innen kultur og turisme.

Kulturdimensjonen måler oppfatningen av de nordiske landenes kulturarv, kulturprodukter og prestasjoner innen sport. Vi ser at Sverige, Norge og Finland ikke har så gode resultater innenfor disse kategoriene.

Også innenfor turisme, ser vi at Norge, Sverige og Finland ikke oppfattes så positivt. Omverdenen mener de ikke har så imponerende historiske bygninger og monumenter, og Finland og Norge ligger ikke i toppen i kategorien for et levende byliv. Islands resultater i Futurebrands undersøkelse fra 2014-2015 viser de samme tendensene.

FutureBrands undersøkelse fra 2014-2015 forsterker inntrykket av at de nordiske landene ikke skårer så høyt innen turisme, kulturarv og kultur. I disse kategoriene er det ingen nordiske land innenfor topp ti i den undersøkelsen.

\section{Stødige varemerker til tross for til dels negativ medieomtale i det siste}

Vår gjennomgang av de forskjellige undersøkelsene tyder på at de nordiske landenes omdømme er ganske stabile og robuste. Et tegn på dette er at de nordiske landenes plasseringer på The Anholt-GfJ Roper Nation Brands Index har variert lite i løpet av de siste årene. Finland har kommet på 17-18. plass i perioden 2008 - 2016. Norge var bare omfattet av undersøkelsen i 2008 og 2014, og havnet begge gangene på en 13. plass. Sverige har også hatt en stabil plassering over tid, 10. plass både i 2014, 2016 og 2017.

Videre viser noen undersøkelser at Danmark og Sveriges omdømme har klart seg relativt godt, selv om de to landene har opplevd negativ omtale i utenlandske medier i forbindelse med flyktningkrisen. 
I 2017 undersøkte Svenska Institutet hvordan Sverige og det svenske samfunnet ble oppfattet i USA og Canada. Bakgrunnen var at både tradisjonelle og sosiale medier i Nord-Amerika hadde vist en økt interesse for Sverige og svensk politikk, og fremfor alt for migrasjons- og integrasjonsspørsmål. Ifølge Svenska Institutet var en stor andel av rapporteringen i media feilaktig og negativ. Et formål med studien var derfor å undersøke hvordan mediebildet påvirket allmennhetens oppfatning av Sverige. Undersøkelsen viste at mediedekningen hadde hatt en relativt begrenset effekt på allmennheten. Folk hadde generelt sett et positivt bilde av Sverige i USA og Canada. Sverige var ganske motstandskraftig mot unyanserte og feilaktige mediebilder. Det var imidlertid fem prosent i Canada og syv prosent i USA som var negative til Sverige, og Svenska Institutet mente man måtte være på vakt mot at denne andelen kunne vokse fremover. ${ }^{11}$

En lignende undersøkelse Svenska Institutet gjennomførte i syv europeiske land, inkludert Norge og Danmark, viste at medierapporteringen om flyktningkrisen i Sverige og Sveriges endring av flyktningpolitikken har hatt et visst, men ikke omfattende, gjennomslag hos respondentene. Respondentenes generelle oppfatning av det svenske samfunnet synes ikke å ha blitt nevneverdig påvirket av mediedekningen internasjonalt eller til dels fiendtlige samtaler i sosiale medier. ${ }^{12}$

I Danmark ble det også gjennomført en studie av om Danmarks omdømme har blitt påvirket av en negativ utenlandsk mediedekning av Danmarks flyktningpolitikk. Undersøkelsen viste at Danmarks omdømme i USA, Storbritannia, Tyskland og Sverige fortsatt var godt. Den massive utenlandske mediekritikken hadde tilsynelatende ikke hatt en alvorlig effekt på Danmarks omdømme blant den allmenne befolkningen. ${ }^{13}$

Ettersom vi tidligere har sett at de Sverige, Finland og Norge skårer veldig likt i på The Anholt-GfJ Roper Nation Brands Index, er det nærliggende å tro at også de andre nordiske landenes omdømme er ganske motstandsdyktige.

Svenska Institutet (2017). Bilden av Sverige $i$ Kanada og USA

Svenska Insitutet (2017). Bilden av Sverige efter flyktningkrisen - En studie $i$ sju europeiska länder Infomedia (2016). Strømninger i flygtningedebatten - En medie- og befolkningsanalyse af den danske flygtningedebat - i Danmark og i udlandet 


\section{Konklusjon}

Denne undersøkelsen tyder på at de nordiske landene generelt oppfattes positivt av andre land. De ligger ganske høyt på tre undersøkelser som rangerer land etter hvor sterke deres varemerker er.

Undersøkelsen tyder også på at de nordiske landenes styresett og samfunnsmodeller oppfattes positivt av omverdenen. Tendensen er at de nordiske landene ligger høyt på listene innenfor disse kategoriene. Det indikerer at de nordiske landene ses på som land som styres godt, som behandler borgerne bra og som sørger for fred og sikkerhet.

De nordiske landene ser også ut til å ha ganske motstandsdyktige varemerker, som tåler litt negativ omtale. Det tyder blant annet undersøkelser av Sveriges og Danmarks omdømme etter flyktningkrisen på.

Denne undersøkelsen gir dermed ganske sterke indikasjoner for å hevde at omverdenen har et godt inntrykk av Nordens samfunnsmodell, noe som er viktig for at Norden skal lykkes med å eksportere sine løsninger og modeller til omverdenen. 


\section{Vedlegg: Om de forskjellige undersøkelsens metode}

Futurebrand 2014-2015 måler hvordan 118 land oppfattes av 2530 respondenter fra 17 land (USA, Canada, Brasil, Argentina, Mexico, Storbritannia, Tyskland, Frankrike, Russland, Tyrkia, Sør-Afrika, De forente arabiske emirater, India, Kina, Thailand, Japan og Australia.) Respondentene defineres som "opinionformers and frequent business and leisure travellers", og er ikke representative for hele befolkningen. De er valgt ut basert på at de kjenner landene som dekkes av undersøkelsen, reiser til utlandet og er mellom 21-65 år gamle. Undersøkelsen måler hvordan landene oppfattes av respondentene, fra at man er kjenner til landet, til at man vil anbefale det. Den legger vekt på hvilke positive egenskaper respondentene assosierer med landet. Landenes styrke som varemerke rangeres mot hverandre, fra sterkest til dårligst.

Anholt-Gfk Roper Nation Brands Index Report 2016 undersøker i likhet med Futurebrand styrken i lands varemerke, eller «image». Undersøkelsen er basert på minst 1000 intervjuer med den delen av befolkningen som er på nett i 20 land (USA, Canada, Storbritannia, Tyskland, Frankrike, Italia, Sverige, Russland, Polen, Tyrkia, Japan, Kina, India, Sør-Korea, Australia, Argentina, Brasil, Mexico, Egypt og Sør-Afrika). Den måler hvordan respondentene oppfatter seks dimensjoner ved landene: Eksportvarer, styresett, kultur, folk, turisme og immigrasjon og investeringer. Til slutt rangeres landene mot hverandre. Island og Norge var ikke med i undersøkelsen i 2016. Norge var med i undersøkelsen i 2014.

Country RepTrak - The Worlds Most Reputable Countries måler hvor godt et lands omdømme er. Den bygger på tre dimensjoner: Respondentenes oppfatning av hvordan det er å bo i landet, om det styres godt og graden av utvikling. De to første temaene tillegges mest vekt. Undersøkelsen er basert på nettintervjuer med 39000 konsumenter fra G8 landene (Canada, Frankrike, Tyskland, Italia, Japan, Russland, Storbritannia og USA) og de oppgir sin mening om de 55 største økonomiene i verden. 


\section{Kilder}

Dinnie, Keith (2017). Nation Branding, Concepts, Issues, Practice. Routledge.

Finland Promotional Board (2016). Results for Finland, The Anholt-GFK Roper Nation Brands Index, 2016 Report, Summary of Finland's nation brand in year 2016.

GfK Public Affairs \& Corporate Communications (2014). The Anholt-GfK Roper Nation Brands Index 2014 Report Prepared for Norway.

Infomedia (2016). Strømninger i flygtningedebatten - En medie- og befolkningsanalyse af den danske flygtningedebat - i Danmark og i vdlandet.

nation-brands.gfk.com (tilgått 1.6.2017), https://nation-brands.gfk.com.

Nordisk ministerråd (2015). Strategi for internasjonal profilering og posisjonering av Norden 2015-2018.

Norden.org (tilgått 1.6.2017). Nordic Solutions to Global Challenges. http://www.norden.org/en/theme/nordic-solutions-to-global-challenges/nordic-solutions-to-global-challenges.

Nye, Joseph (2005). Soft Power - The Means to Success in World Politics. Public Affairs.

Svenska Institutet (2017). Bilden av Sverige i Kanada og USA.

Svenska Institutet (2017). Bilden av Sverige efter flyktningkrisen - En studie $i$ sju europeiska länder.

Visit Sweden (2017) Den Internationella bilden av Sverige som land - Så står Sverige $i$ världen enligt Nation Brands Index. 
Nordisk ministerråd

Nordens Hus

Ved Stranden 18

DK-1061 København K

www.norden.org

Dette notat handler om hvordan omverdenen oppfatter de nordiske landene. Det er viktig, ettersom det påvirker blant annet handel, investeringer og turisme.

Undersøkelsen gir ganske sterke indikasjoner for å hevde at omverdenen har et godt inntrykk av Nordens samfunnsmodell, noe som er viktig for at Norden skal lykkes med å eksportere sine løsninger og modeller til omverdenen. 